\title{
New Insight Towards Prognosis in Pediatric Acute Myeloid Leukemia: Comparative Study
}

\author{
Nihal S. IBRAHIM ${ }^{1}$, Huda MARZOUK ${ }^{2}$, Noha Y. IBRAHIM ${ }^{3}$ \\ ${ }^{1}$ Cairo University, Faculty of Medicine, Department of Clinical and Chemical Pathology \\ ${ }^{2}$ Cairo University, Faculty of Medicine, Department of Pediatric \\ ${ }^{3}$ Cairo University, Faculty of Medicine, Department of Pediatric Oncology, Cairo, EGYPT
}

\begin{abstract}
Wilms tumor gene (WT1) is a reliable marker for minimal residual disease assessment in acute leukemia children. This study was designed to demonstrate the potential use of WT1 to establish quality of remission in acute leukemia children for early identification of children at high risk of relapse. This study based on a quantitative Real-Time polymerase chain reaction (PCR) (TaqMan) assay in bone marrow samples collected from 45 acute myeloid leukemia children at diagnosis and during follow-up was established. Our results revealed, there was no significant association between WT1expression,at diagnosis, and either of gender, organomegally, total leucocytic count (TLC), French-American- British system (FAB) subtypes, CD34 expression, cytogenetic studies, percentage of blast infiltration or response to induction therapy. By comparing the results obtained at day 14 and those obtained at day 28, we cannot depend on WT1gene expression or MRD detection at day 14 in predicting resistance to treatment or predicting mortality $(p=0.12)$. In contrast WT1 gene expression or MRD detection values after induction therapy (at day28) is an independent prognostic risk factor of relapse $(p=0.001)$ and death $(p=0.001)$. The blast percentage was significantly correlated to the WT1expression levels at day 28 . The presence of MRD or WT1gene expression at the end of induction therapy is an extremely powerful adverse prognostic factor.WT1 at presentation has no prognostic significance whereas a high WT1 expression after induction therapy is a predictor for poor outcome. A rise inWT1expression during treatment is a predictor for relapse. WT1 expression is a valuable and important tool for MRD study in AML and the presence of MRD value at the end of induction therapy is an extremely powerful adverse prognostic factor despite of achievement of morphological remission.
\end{abstract}

Keywords: Wilms tumor gene 1, Acute myeloid leukemia, Minimal residual disease

\section{ÖZET}

\section{Pediatrik Akut Miyeloid Lösemi Prognozunu Anlamada Yeni Görüşler: Karşılaştırmalı Çalışma}

Akut çocukluk dönemi lösemilerde minimal rezidüel hastalığı göstermede Wilms tümör geni (WT1) güvenli bir belirteçtir. Bu çalışma yüksek riskli akut lösemili çocuklarda remsiyon kalitesini ve erken relapsları göstermede WT1 kullanımının potansiyel yerini araştırmak için planlanmıştır. Bu çalışmada 45 akut myeloid lösemili çocuk hastanın Real-Time polimeraz zincir reaksiyonu (PCR) (TaqMan) testi kullanılarak tanı anı ve takip kemik iliği örnekleri incelenmiştir. Çalışmamızın sonuçlarında; tanı anında WT1 ekspresyonu ile cinsiyet, organomegali, toplam lökosit sayıSı, FAB sınıflaması alt tipi, CD34 ekspresyonu, sitogenetik çalışmalar, tanı anındaki blast oranı ve indüksiyon tedavisine yanıt arasında herhangi bir ilişki saptanamamışır. 14. gün ve 28. gün örnekleri değerlendrildiğinde; 14. gün örneklerinde bakılan WT1 gen ekspresyonunun veya minimal rezidüel hastalık (MRD) tedaviye direnç veya mortaliteyi saptamada güvenili bir yöntem olmadığı gösterilmiştir $(p=0.12)$. Ancak indüksiyon tedavisi sonrası (28. gün) WT1 gen ekspresyonu veya MRD saptanması relaps $(p=0.001)$ ve mortalite $(p=0.001)$ için bağımsız bir prognostik factor olarak saptanmıştır. Yirmi sekizinci gün WT1 ekspresyonu ile blast oranı arasında istatistiksel olarak anlamlı korelasyon saptanmıştır. İndüksiyon tedavisi sonunda MRD varlığı veya WT1 gen ekspresyonu önemli kötü prognostik faktörlerdir. Tanı anında WT1 ekspresyonunun prognostic bir önemi yoktur, ancak indüksiyon tedavisi sonrası WT1 ekspresyonu kötü prognostik seyirin bir belirtecidir. Tedavi sürecinde WT1 ekspresyonunda artış relaps için bir prediktördür. WT1 ekspresyonu, MRD çalışımasında önemli bir araçtır. İndüksiyon tedavisi sonrası MRD varlı̆̆ı, morfolojik olarak remisyon sağlansa bile bu durum kötü bir prognostik faktördür.

Anahtar Kelimeler: Wilms tümör geni 1, Akut miyeloid lösemi, Minimal rezidüel hastalık 


\section{INTRODUCTION}

Acute myeloid leukemia (AML) accounts for 15 percent of childhood leukemia's and 5 percent of all childhood cancer, highest risk in children aged less than 2 years; the risk in children aged 2-9 years is lower and it then rises through the adolescent years. Boys develop AML more than girls by ratio of 5:4 with no reason known. ${ }^{1}$ Around two-third of children with AML are cured, the cure rate is higher for patients who receive a matched sibling stem cell transplant in first remission than for patients treated with chemotherapy alone. The prognosis for relapsed AML is poor. Infant less than 1 year and children aged 10-14 years have lower survival than children diagnosed at intermediate ages. Survival is highest for children with M3 sub-type. ${ }^{2}$

After treatment of AML in children, either is in remission or in minimal residual disease (MRD). In general, children with detectable MRD during or after induction chemotherapy are more likely to develop relapse and may require more intense treatment ${ }^{2}$ Evaluation of MRD in children with AML after induction therapy is important to predict prognosis and may improve selection of the type and intensity of post-remission treatment. ${ }^{1}$

One of the main goals of MRD monitoring is represented by the possibility of identifying as soon as possible after induction therapy the subset of patients who, although in complete morphologic remission (CR), present a high risk of relapse. This means these patients can be treated with intensified chemotherapy protocols. ${ }^{2}$

The major obstacle in MRD detection by RT-PCR or quantitative PCR (RQ-PCR) is represented by the limited percentage of AML patients presenting with detectable genetic aberrations. ${ }^{3}$ The use of alternative markers for MRD detection suitable in the vast majority of AML patients, and in particular to test WT1 expression as a universal marker of leukemic cells. ${ }^{2}$

The Wilms tumor gene (WT1.) The gene is located on the short arm of chromosome 11(11p13) and contains 10 exons and generates a $3 \mathrm{~kb}$ mRNA., initially characterized as a tumor suppressor gene, was first identified as a gene responsible for childhood kidney neoplasm. It also a transcription fac- tor important for normal cellular development and cell survival. WT1 has been shown to be highly expressed in several hematopoietic tumors including AML. ${ }^{4}$

The aim of this work is to study if quantitative assessment of the Wilms' tumor (WT1) gene by real time polymerase chain reaction (RQ-PCR) can be used as a marker for MRD detection during the monitoring of AML and also to assess the prognostic relevance of its expression.

\section{PATIENTS and METHODS}

This study included 45 children with acute myeloid leukemia. They were 26 males and 19 females. Their age ranged from 1 year to 18 years. They were 43 newly diagnosed and 2 relapsed children. The patients were diagnosed and treated at Ceizium department, Cairo University. The study was approved by the Cairo University Clinical Research Ethics Committee, and informed consents were obtained from the parents of all participates.

For all patients, thorough history taking, including demographic data and the first presenting symptoms which suggest the malignancy, together with full physical examination at the time of study with emphasis on lymph node swelling, patches of discoloration and petechie, organomegally and weight.

The patients were subjected to the following:

- Routine laboratory investigation to establish the diagnosis of AML including (CBC, BMA for FAB classification, cytochemistry and immunophenotyping).

- Cytogenetic analysis and screening for the presence of the most frequent fusion transcripts [such as $\mathrm{t}(8 ; 21), \mathrm{t}(15 ; 17)]$ were done to some patients [n=26/45].

- Quantitative assessment of WT1 gene expression by real-time polymerase chain reaction (RQ-PCR) in patients with AML at diagnosis as well as during day 14 (for 10 cases) and after anti leukemic therapy day 28 ( for 31 cases ). Also the assessment of WT1 gene expression in BM samples of normal healthy donors $(n=6)$ was done as a control group 
in order to define the normal range of WT1expression in healthy subjects.

The mononuclear cells were separated and total cellular RNA was extracted from the mononuclear cells using the QIA amp RNA blood Mini kit (QIAGEN, Catalogue number. 52304), followed by cDNA preparation using a high capacity cDNA archive kit (Applied Biosystem, Foster city, CA, USA).

Agarose gel electrophoresis was done prior to analysis to confirm the presence of c-DNA. The WT1 Profile Quant ${ }^{\mathrm{TM}}$ Kit (PQPP-01) is a research tool intended for the accurate normalized quantification of WT1 gene transcripts in bone marrow samples of AML patients using ABI Prism (7700) TaqMan instruments.

According to the method done by Barjesteh et al. ${ }^{5}$ using $25 \mu \mathrm{l}$ mix containing $5 \mu \mathrm{l}$ sample cDNA, $12.5 \mu 1$ master mix, $1 \mu 1$ of IPSOGEN primers and Probe (either PPC-ABL or PPP-WT1) and 6.5 nuclease free water. $5 \mu \mathrm{l}$ water instead of cDNA was used as control .

The thermal cycler conditions were 10 minutes at $95^{\circ} \mathrm{C}$ followed by 45 cycles of denaturation for 15 seconds at $95^{\circ} \mathrm{C}$ and, annealing /extension at $60^{\circ} \mathrm{C}$ for 30 seconds.

The normalized copy number of WT1 (WT1$\mathrm{NCN})$ is defined the ratio of copy number $(\mathrm{CN})$ of the target gene [WT1 gene] to the copy number of the control gene [ABL gene] done during the same assay: 6,7

\section{$\mathrm{WT} 1-\mathrm{NCN}=(\mathrm{WT} 1-\mathrm{CN} / \mathrm{ABL}-\mathrm{CN})$}

In the NCN method, the minimal residual disease (MRD) value is a ratio between the normalized copy number of WT1 during follow up (at day 14 or day 28) and the normalized copy number of WT1 in diagnostic sample.

MRD at day $14=\mathrm{WT} 1-\mathrm{NCN}$ at day14/WT1-NCN at diagnosis

MRD at day $28=\mathrm{WT} 1-\mathrm{NCN}$ at day $28 / \mathrm{WT} 1-\mathrm{NCN}$ at diagnosis

\begin{tabular}{|ll|}
\hline $\begin{array}{l}\text { Table 1. Summarized the main clinical manifestation of our } \\
\text { patients }\end{array}$ \\
\hline History and clinical manifestations & Number \\
\hline Splenomegaly & 27 \\
Hepatomegaly & 20 \\
Painless swelling in the neck & 19 \\
Bone tenderness & 17 \\
Tiredness & 17 \\
Unusual bleeding and bruising & 10 \\
Recurrent and frequent infection & 9 \\
Night sweet & 7 \\
Paleness & 7 \\
Weight loss & 3 \\
\hline
\end{tabular}

\section{Statistical Analysis}

Data were statistically described in terms of range, mean, standard deviation $( \pm \mathrm{SD})$, frequencies (number of cases) and relative frequencies (percentages) when appropriate. Comparison of quantitative variables between poor and good prognosis groups in the present study was done using Mann Whitney U test for independent samples. Comparison of quantitative variables according to favorability groups was done using Kruskal Wallis analysis of variance (ANOVA) test with posthoc multiple 2-group comparisons. For comparing categorical data, Chi square (X2) test was performed. Yates correction was used in stead when the expected frequency is less than 5 . A probability value ( $\mathrm{p}$ value) less than 0.05 was considered statistically significant. All statistical calculations were done using computer programs Microsoft Excel version 7 (Microsoft Corporation, NY, USA) and SPSS (Statistical Package for the Social Science; SPSS Inc., Chicago, IL, USA) statistical program.

\section{RESULTS}

The study included 45 Egyptian children with AML, 26 males and 19 females. The most frequent clinical manifestations were hepatomegaly, splenomegaly, painless swelling in the neck, bone tenderness, followed by tiredness and unusual bleeding and bruising (Table 1). 
International Journal of Hematology and Oncology

\begin{tabular}{|c|c|c|c|c|}
\hline \multirow[t]{2}{*}{ Variables } & \multirow[t]{2}{*}{ No. } & \multicolumn{2}{|c|}{ WT1-NCN } & \multirow[t]{2}{*}{ p-value } \\
\hline & & Median & Min.-Max. & \\
\hline \multicolumn{5}{|l|}{ Gender: } \\
\hline Female & 19 & $6.3 \times 10^{-2}$ & $0.00-3.98 \times 10^{2}$ & $0.82^{*}$ \\
\hline Male & 26 & $2.066 \times 10^{-2}$ & $0.00-6.81 \times 10^{3}$ & \\
\hline \multicolumn{5}{|l|}{ Organomegaly } \\
\hline \multicolumn{5}{|l|}{ Hepatomegaly } \\
\hline +ve & 20 & 0.682 & $0.00-6.81 \times 10^{3}$ & $0.09^{*}$ \\
\hline -ve & 25 & $1.07 \times 10^{-4}$ & $0.00-3.98 \times 10^{2}$ & \\
\hline \multicolumn{5}{|l|}{ Splenomegaly } \\
\hline+ ve & 27 & 0.158 & $0.00-1.17 \times 10^{3}$ & $0.21^{*}$ \\
\hline -ve & 18 & $5.7 \times 10^{-5}$ & $0.00-6.81 \times 10^{3}$ & \\
\hline \multicolumn{5}{|c|}{ Laboratory findings } \\
\hline \multicolumn{5}{|c|}{ TLC: } \\
\hline$\leq 50.000$ & 28 & $2.86 \times 10^{-4}$ & $0.00-6.81 \times 10^{3}$ & $0.47^{\star}$ \\
\hline$>50.000$ & 17 & 0.1 & $0.00-6.81 \times 10^{2}$ & \\
\hline \multicolumn{5}{|l|}{ CD34 expression } \\
\hline$+\mathrm{ve}$ & 29 & $4.6 \times 10^{-4}$ & $0.00-6.81 \times 10^{2}$ & $0.17^{\star}$ \\
\hline$-v e$ & 16 & 0.87 & $0.00-6.81 \times 10^{3}$ & \\
\hline \multicolumn{5}{|c|}{ FAB classification } \\
\hline Mo-M1 & 16 & $4.85 \times 10^{-3}$ & $0.00-6.81 \times 10^{2}$ & $0.41^{\star \star}$ \\
\hline M2 & 20 & 0.104 & $0.00-6.81 \times 10^{3}$ & \\
\hline M4-M5 & 8 & $5 \times 10^{-2}$ & $0.00-100$ & \\
\hline \multicolumn{5}{|c|}{ Cytogenetic studies } \\
\hline Favorable & 6 & $1.58 \times 10^{-2}$ & $0.00-0.14$ & $0.25^{\star *}$ \\
\hline Intermediate & 16 & 0.53 & $0.00-6.8 \times 10^{3}$ & \\
\hline Unfavorable & 4 & $1.78 \times 10^{-5}$ & $3.69 \times 10^{-9}-1.58$ & \\
\hline \multicolumn{5}{|c|}{ Response to induction therapy } \\
\hline \multicolumn{5}{|c|}{ Complete remission: } \\
\hline Achieved & 22 & $4.73 \times 10^{-2}$ & $0.00-6.8 \times 10^{3}$ & $0.94^{*}$ \\
\hline Not achieved & 23 & $9.69 \times 10^{-3}$ & $0.00-3.98 \times 10^{2}$ & \\
\hline
\end{tabular}

The WT1 expression was almost undetectable in all analyzed normal bone marrow samples. Thus the detectable levels observed among the studied AML patients were considered as significant expression. WT1 over expression was detected in 41 out of the 45 AML patients $(91 \%)$ studied at diagnosis.

In the present study, the results obtained (by using WT1-NCN and MRD) can be used to monitor efficiency of treatment in patients undergoing therapy and for follow-up to monitor disease relapse.

Patients were classified according to their clinical and biological variables at time of diagnosis .
WT1 gene expression level were compared among these groups. There was no significant association between WT1 gene and either gender, organomegally, TLC, FAB subtype, CD34 expression, cytogenetics studies or response to induction therapy (Table 2).

The impact of WT1 expression level on the overall survival (OS) and event free survival (EFS) was determined by COX regression analysis at diagnosis, there was no significant impact on OS ( $\mathrm{p}=$ $0.88)$ and $\mathrm{EFS}(\mathrm{p}=0.82)$ 
Table 3. Correlation between WT1 expression levels and blast percentage at diagnosis, in the 10 studied patients at day 14 , and in 31 studied patients at 28 days

\begin{tabular}{|c|c|c|}
\hline & \multicolumn{2}{|c|}{ WT1-NCN } \\
\hline & $\mathbf{r}$ & $\mathbf{p}$ \\
\hline Blast $\%$ at diagnosis & 0.23 & $0.15^{\star}$ \\
\hline Blast \% at day 14 & -0.69 & $0.03^{*}$ \\
\hline Blast \% at day 28 & 0.45 & $0.01^{\star}$ \\
\hline \multicolumn{3}{|c|}{$\begin{array}{l}\text { * Calculated by Spearman's correlation Test. p-value }<0.05=\text { sig } \\
\text { nificant. }\end{array}$} \\
\hline
\end{tabular}

BM samples were available from 10 patients and were analyzed to follow the level of expression of WT1 during induction treatment. It showed significant negative correlation to the WT1 expression levels at day $14(\mathrm{p}=0.03)$. This means we cannot depend on WT1 level at day 14 to evaluate the response.

The blast percentage was significantly correlated to the WT1expression levels at day 28. This may support the suggestion that WT1 expression could reflect the leukemia burden (Table 3).

Patients survived till day 28 were classified into two groups either relapsed or not relapsed. WT1 over-expression at day 28 was significantly associated with increased incidence of relapse $(\mathrm{p}=0.001)$.

On using MRD values instead of WT1-NCN values, in early detection of relapse, MRD values revealed also significant association with increased incidence of relapse $(\mathrm{p}=0.001)$. Thus either WT1NCN or MRD values at day 28 can be used to predict relapse (Table 4).
By comparing the results obtained at day 14 and those obtained at day 28, we cannot depend on WT1-NCN gene expression or MRD detection at day 14 in predicting resistance to treatment or predicting mortality. In contrast WT1-NCN gene expression or MRD detection after induction therapy (at day 28) is an independent prognostic risk factor of death $(\mathrm{p}=0.001)$ (Table 5).

ROC analysis was done to detect the sensitivity and specificity of WT1-NCN and MRD at day 28 in early detection of relapse revealed that WT1NCN level above 28.3 cutoff and MRD above $1.6 \times 10^{9}$ raise the incidence of relapse to $95 \%$ and $100 \%$ respectively.

\section{DISCUSSION}

Accurate assessment of MRD in children with AML after initial chemotherapy is essential to evaluate the efficacy of treatment regimens, to establish early diagnosis of impending relapse, and to individualize treatment protocols. Detection of early relapse, allow intervention at a more favorable stage than at overt relapse. The mainstays of MRD studies include molecular tests, such as RTPCR amplification of chromosomal translocations and multidimensional flow cytometry detection of aberrant phenotypes. ${ }^{8,9}$

Unfortunately, MRD detection by RT-PCR or quantitative PCR (RQ-PCR) is faced by major obstacle which is the limited percentage of AML children presenting with detectable genetic aberrations since gene abnormalities can be detected in only $30 \%$ of patients with AML. This promoted

Table 4. The role of WT1-NCNgene expression and MRD detection at day 28, in early detection of relapse

\begin{tabular}{|c|c|c|c|}
\hline & \multicolumn{2}{|c|}{ Outcome } & \multirow[t]{2}{*}{$p$ - value } \\
\hline & Relapsed & Not relapsed & \\
\hline Cases: No (\%) & $11(35.4 \%)$ & $20(64.5 \%)$ & \\
\hline \multicolumn{4}{|l|}{ WT1-NCN } \\
\hline Median & 17 & $8.3 \times 10^{-11}$ & \\
\hline Mean \pm SD & $1.7 \times 10^{3} \pm 4.3 \times 10^{3}$ & $4.3 \times 10^{2} \pm 1.9 \times 10^{3}$ & $0.001^{*}$ \\
\hline \multicolumn{4}{|l|}{ MRD-28 } \\
\hline Median & $5.8 \times 10^{4}$ & $5.4 \times 10^{-10}$ & \\
\hline Mean \pm SD & $2.4 \times 10^{9} \pm 5.4 \times 10^{9}$ & $7.9 \times 10^{7} \pm 3.5 \times 10^{8}$ & $0.001^{*}$ \\
\hline
\end{tabular}


Table 5. The role of WT1-NCN and MRD detection at day 28 in predicting mortality

\begin{tabular}{|c|c|c|c|}
\hline & \multicolumn{2}{|c|}{ Outcome } & \multirow[t]{2}{*}{$p$-value } \\
\hline & Death & Alive & \\
\hline Cases: No (\%) & $14(45.2 \%)$ & 17 (54.8\%) & \\
\hline \multicolumn{4}{|l|}{ WT1-NCN } \\
\hline Median & 1.6 & $6.8 \times 10^{-11}$ & \\
\hline Mean \pm SD & $1.9 \times 10^{3} \pm 4.29 \times 10^{3}$ & $4.3 \times 10^{-2} \pm 1.78 \times 10^{-1}$ & $0.001^{*}$ \\
\hline \multicolumn{4}{|l|}{ MRD } \\
\hline Median & $1.4 \times 10^{5}$ & $5.8 \times 10^{-14}$ & \\
\hline Mean \pm SD & $1.9 \times 10^{9} \pm 4.8 \times 10^{9}$ & $3.4 \times 10^{3} \pm 1.4 \times 10^{4}$ & $0.001^{*}$ \\
\hline
\end{tabular}

several investigators to search for alternative markers for MRD detection suitable in the vast majority of AML patients. In the last few years, the Wilms' tumor gene (WT1) expression has been suggested as a universal marker of leukemic cells. ${ }^{10}$

This work aimed to analyze WT1 expression levels at diagnosis and during follow up of AML children treated with standard chemotherapy protocols to identify the subset of patients that are at high risk of relapse early after induction chemotherapy and the prognostic relevance of WT1 expression at diagnosis and early follow up. WT1 gene expression levels at diagnosis were also correlated with patients' clinical and laboratory findings.

In the present work, WT1 expression was undetectable in all analyzed normal bone marrow samples. On the contrary, WT1 level was over expressed at diagnosis in 41 out of 45 AML patients (91\%) included in this work. In agreement to our results, Yanada et al, Qin et al, and Kim et al, observed WT1 over expression in $92 \%, 91 \%$ of their patients respectively. ${ }^{11-13}$

In the present study, WT1 expression levels in the AML patients at diagnosis were studied in relation to their clinical and laboratory findings. There was no significant association between WT1expression at diagnosis and either of gender, organomegaly, TLC, FAB subtypes, CD34 expression, cytogenetic studies, or response to induction therapy. In accordance with these results, Lapillonne et al, stated that, there were no significant associations between WT1 levels at diagnosis, WBC, cytogenetic groups (favorable or unfavorable) or induction failure. ${ }^{14}$

In this work, there was no statistically significant difference as regard WT1 expression level among different FAB subtypes. This is in consistent with Garg et al, Barragan et al, and Ostergaard et al, who did not find any association between WT1 expression and FAB subtype. ${ }^{15-17}$ However, Bergmann et al, and Lapillonne et al, showed that WT1 values were significantly lower in M5-FAB subtype. ${ }^{18,14}$ This may be an evidence of an inverse correlation between WT1expression and differentiation. This could not be demonstrated in this work, may be due to small number of AML patients with M5 FAB subtype ( 3 out of 45 patients).

As demonstrated by Wiesser et al, the present work, showed no significant correlation between WT1 expression levels and the blast percentage at diagnosis. This may suggest that the blast cells may not be the only source of the expressed WT1 in leukemic patients but it is related to the whole malignant population. ${ }^{19}$

Twenty six studied AML patients were classified according to their cytogenetic studies into favorable, intermediate and unfavorable risk groups. No significant difference regarding WT1 expression among the three groups could be elicited in this study. This comes in consistency with Barragan et al, who did not find any association between WT1 ratio and cytogenetic risk groups. ${ }^{16}$ Some other reports showed, karyotypically favorable AML subgroups were associated with either high or with very low levels of WT1 expression..$^{20,17}$ 
In the present work, the influence of WT1 expression levels at diagnosis on the overall survival (OS) and event-free survival (EFS) was determined by COX regression analysis, using WT1 gene expression at diagnosis as a continuous variable in 45 patients. There was no significant impact on OS $(p=$ $0.88)$ or on EFS $(\mathrm{p}=0.82)$. Thus there was no association between initial WT1 levels and outcome in terms of event-free survival or overall survival. This comes in consistency with Yanada et al, Lapillonne et al, Kim et al, and Hämäläinen et al, who reported that higher levels of WT1 gene expression at diagnosis were not associated with shorter EFS or OS at diagnosis. ${ }^{7,11,13,14}$

During treatment induction WT1 expression was assayed at day 14 for 10 patients and at day 28 for 31 patients. The results were expressed as either WT1-NCN or MRD value. At day 14, neither WT1-NCN gene expression nor MRD values were of significant value in predicting resistance to treatment or predicting mortality $(\mathrm{p}=0.12)$. In contrast both WT1-NCN gene expression and MRD values at day 28 after induction therapy were independent prognostic risk factors of relapse $(\mathrm{p}=0.001)$ and death $(\mathrm{p}=0.001)$. The presence of MRD or WT1$\mathrm{NCN}$ gene expression at the end of induction therapy is an extremely powerful adverse prognostic factor. These results are in consistent with Lapillonne et al, who showed that WT1 ratio $>50$ after induction is an independent prognostic risk factor of relapse and death. ${ }^{14}$

Also WT1 expression levels measured at day 14 and day 28 and expressed as WT1-NCN was correlated with blast percentage usually used as a morphological evidence of relapse although it has limited sensitivity. This was done to show whether WT1 expression levels could help in the detection of a potential relapse.

At day 14 the bone marrow blast percentage showed significant negative correlation to the WT1 expression levels. The low number of cases and the probability of chances make these results not to be raised to statistical conclusion especially because it is not supported by other studies. At day 28 the blast percentage was positively correlated to the WT1 expression levels. Thus increasing values of WT1 expression during follow up are associated with relapse evidenced by progressive increase in blast percentage.

Cilloni et al, Qin et al, Polák et al, and Kim et al, also concluded that continuous or significant increase of WT1 expression in complete hematological remission patients predicts an impending relapse as early as 2 months in advance of clinical relapse. This early detection of patients at high risk of relapse may provide sufficient time for development of second-line treatment strategies. ${ }^{12,13,23,24}$

In the present work, WT1 expression levels in 2 out of 31 AML cases studied did not correlate to their clinical course. Despite of their low MRD values during follow up, they had poor outcome (one died and the other was resistant to treatment). Thus MRD detection using only MRD values was $100 \%$ specific predictor of poor prognosis but it was less sensitive and less accurate than combined use of both BM examination for blasts and MRD values. This comes in consistency with Wiesser et al, reported that WT1 levels at relapse remained in the range of the prior sample of cytomorphological remission. ${ }^{18}$ However as shown in this work, this was observed in a very limited number of their patients.In conclusion, quantitative assessment of WT1 using sensitive and specific technique such as quantitative real time RT-PCR could allow accurate assessment of MRD in the majority of AML patients. Single assessment of WT1 expression at diagnosis may be of limited prognostic value and it did not have a significant impact on OS and EFS. WT1 expression is a valuable and important tool for MRD study in AML and the presence of MRD at the end of induction therapy is an extremely powerful adverse prognostic factor despite of achievement of morphological remission.

\section{Acknowledgments}

The authors thank El-Kasr El-Aini Hospital, Cairo University, Cairo, Egypt for helping in performing this study and also the patients for their willing participation in this research. 


\section{REFERENCES}

1. Sugiyama H. WT1 (Wilms' Tumor Gene 1): Biology and Cancer Immunotherapy. Jpn J Clin Oncol 40: 377-387, 2010.

2. Cilloni $D$, Messa F, Arruga F, et al. Early prediction of treatment outcome in acute myeloid leukemia by measurement of WT1 transcript levels in peripheral blood samples collected after chemotherapy. Haematologica 93: 921-924, 2008.

3. Al-Mawali A, Gillis D, Lewis I. The role of multiparameter flow cytometry for detection of minimal residual diseaseofin acute myeloid leukaemiaaa. Am J Clin Pathol 131: 16-26, 2009.

4. Keilholz U, Menssen HD, Gaiger A, et al. Wilms' tumour gene 1 (WT1) in human neoplasia. Leukemia 19: 1318-1323, 2005.

5. Barjesteh van Waalwijk van Doorn-Khosrovani, Erpelinck C, van Putten WL, et al. High EVI1 expression predicts poor survival in acute myeloid leukemia: a study of 319de novo AML patients. Blood 101: 837-845, 2003.

6. Cilloni D, Saglio G. WT1 as a universal marker for minimal residual disease detection and quantification in myeloid leukemias and in myelodysplastic syndrome. Acta Heamatol 112: 79-84, 2004.

7. Hämäläinen $M M$, Kairisto $\mathrm{V}$, Juvonen $\mathrm{V}$, et al. Wilms tumour gene 1 overexpression in bone marrow as a marker for minimal residual disease in acute myeloid leukemia. Eur J Haematol 80: 201-207, 2008.

8. Rubnitz JE, Inaba H, Dahl G, et al. Minimal residual disease-directed therapy for childhood acute myeloid leukaemia: results of the AML02 multicentre trial. Lancet Oncol 11: 543-552, 2010.

9. Summers K, Stevens J, Kakkas I, et al. Wilms' tumour 1 mutations are associated with FLT3-ITD and failure of standard induction chemotherapy in patients with normal karyotype AML. Leukemia 21: 550-551, 2007.

10. Gabert J, Beillard E, van der Velden VHJ, et al. Standardization and quality control studies of "real time" quantitative reverse transcriptase polymerase chain reaction of fusion gene transcripts for residual dis $\neg$ ease detection in leukemia: a Europe Against Cancer program. Leukemia 17: 2318-2357, 2003.

11. Yanada M, Terakura S, Yokozawa T, et al. Multiplex real-time RT-PCR for prospective evaluation of WT1 and fusion gene transcripts in newly diagnosed De Novo acute myeloid leukemia. Leuk Lymphoma 45: 1803-1808, 2004.

12. Qin YZ, Ruan GR, Li JL, et al. Significance of quantification of WT1 mRNA for monitoring minimal residual disease in acute myeloid leukemia patients. Zhonghua Xue Ye Xue Za Zhi 26: 649-652, 2005.

13. Kim HR, Shin JH, Lee JN, Lee EY. Clinical significance of quantitation of WT1 gene expression for minimal residual disease monitoring of acute myelogenous leukemia. Korean $\mathrm{J}$ Lab Med 27: 305-312, 2007.

14. Lapillonne H, Renneville A, Auvrignon A, et al. High WT1 expression after induction therapy predicts high risk of relapse and death in pediatric acute myeloid leukemia. $\mathrm{J}$ Clin Oncol 24: 1507-1515, 2006.
15. Garg M, Moore H, Tobal K, Liu Yin JA. Prognostic significance of quantitative analysis of WT1 gene transcripts by competitive reverse transcription polymerase chain reaction in acute leukemia. Br J Hematol 123: 49-59, 2003.

16. Barragán E, Cervera J, Bolufer $\mathrm{P}$, et al. Prognostic implications of Wilms' tumor gene (WT1) expression in patients with de novo acute myeloid leukemia. Haematologica 89: 926-933, 2004.

17. Østergaard M, Olesen LH, Hasle H, et al. WT1 gene expression: an excellent tool for monitoring minimal residual disease in $70 \%$ of acute myeloid leukemia patients: results from a single-centre study. Br J Haematol 125: 590-600, 2004.

18. Bergmann L, Miething C, Maurer U, et al. High Levels of Wilms' Tumor Gene (WT1) mRNA in Acute Myeloid Leukemias Are Associated With a Worse Long-Term Outcome. Blood 90: 1217-1225, 1997.

19. Weisser M, Kern W, Rauhut S, et al. Prognostic Impact of RT- PCR-based quantification of WT1 gene expression during MRD monitoring of acute myeloid leukemia. Leukemia 19: 1416-1423, 2005.

20. Cilloni D, Gottardi E, De Micheli D, et al. Quantitative assessment of WT1 expression by real time quantitative PCR may be a useful tool for monitoring minimal residual disease in acute leukemia patients. Leukemia 16: 2115-2121, 2002.

21. Spanaki A, Linardakis E, Perdikogianni C, et al. Quantitative assessment of WT1 expression in diagnosis of childhood acute leukemia. Leuk Res 31: 570-572, 2007.

22. Greiner J, Schmitt M, Li L, et al. Expression of tumor-associated antigens in acute myeloid leukemia: implications for specific immunotherapeutic approaches. Blood 108: 4109-4117, 2006.

23. Cilloni D, Messa F, Gottardi E, et al. Very significant correlation between WT1 ex $\neg$ pression level and the IPSS score in patients with myelodysplastic syndromes. J Clin Oncol 21: 1988-1995, 2003.

24. Polák J, Marková J, Schwarz J, et al. The use of quantitative assessment of Wilms tumour gene 1 for monitoring of residual disease in acute myeloid leukemia patients. Cas Lek Cesk 145: 36-42, 2006.

\section{Correspondence}

Nihal Salah El Deen IBRAHIM

Cairo University, Faculty of Medicine

Department of Clinical and Chemical Pathology

El-Kasr El-Aini Hospital, El-Manial

CAIRO / EGYPT

Tel: +2-01092725801

Fax: +20-02-33033754

Email: nisalah@gmail.com 